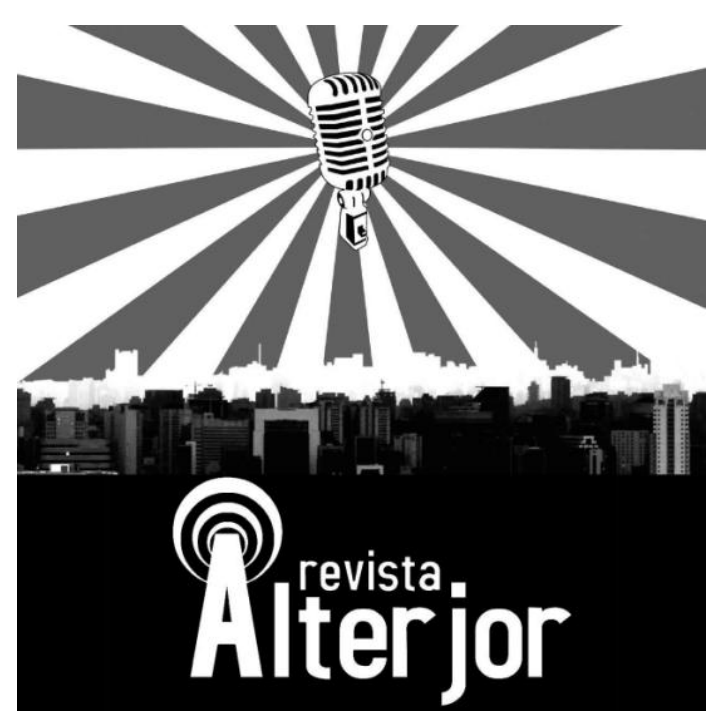

\title{
LONGE DOS GRANDES CENTROS URBANOS: O EXPURGO DO NÃO-EU E O USO DA PRETENSA CREDIBILIDADE DO JORNALISMO EM BLOGS, MICROBLOGS E REDES SOCIAIS DIGITAIS
}

\author{
Patricia Rakel de Castro Sena ${ }^{1}$ \\ Rômulo Magnus de Castro Sena ${ }^{2}$ \\ Ricardo Barbosa Fernandes de Souza $^{3}$ \\ Heitor Costa Lima da Rocha ${ }^{4}$
}

RESUMO: Este artigo apresenta uma análise crítica de discurso sobre as matérias que se pretendem jornalísticas, porque pretendem a credibilidade de carregar em suas publicações o estatuto da verdade, em plataformas digitais e online e que midiatizam regiões interiorana do Brasil, mas especificamente no sertão Potiguar. Este estudo busca categorizar os discursos e analisá-los levando em consideração uma característica recorrente nas eleições político-partidárias: o "expurgo do não-eu", o que se distingue de mim ideologicamente nas práticas sociais políticas, feito não só por candidatos políticos quanto pelos jornalistas ou donos dos meios de comunicação/perfis em plataformas digitais online.

PALAVRAS-CHAVE: Discurso. Política. Jornalismo online. Expurgo do não-eu.

ABSTRACT: This article presents a critical analysis of the articles that are intended to be journalistic, because they want the credibility of carrying the status of truth in their publications. These texts are published on digital and online platforms that mediate inland regions of Brazil, but specifically in the interior of Potiguar. This study aims to categorize the speeches and analyze them taking into account a recurring characteristic in the political-party elections: the "purge of the other" done not only by the political candidate but also by the journalist or owners of the media.

KEYWORDS: Discourse. Policy. Online journalism. Purge of the other.

\footnotetext{
Doutora em Comunicação, pelo Programa de Pós-Graduação em Comunicação, da Universidade Federal de Pernambuco, Atualmente é professora adjunta do Departamento de Comunicação Social da Universidade Federal do Maranhão (UFMA) e do Programa de Pós-graduação em Comunicação. E-mail: rakeldecastro@ gmail.com

${ }^{2}$ Bacharel em Enfermagem pela FCM-CG (2010), Mestre em Psicologia pela UFRN (2015), e Doutorando em Ciências Médicas, na área de concentração em Saúde Mental, pela UNICAMP. E-mail: dcastro@ unicamp.br

${ }^{3}$ Doutor em Comunicação e Informação pela Universidade Federal do Rio Grande do Sul. Mestre em Comunicação Social pela Universidade Federal de Pernambuco. E-mail: fernandesricardo86@gmail.com

${ }^{4}$ Doutor em Sociologia pela Universidade Federal de Pernambuco (2004) e Pós-Doutorado em Comunicação pela Universidade da Beira Interior/Covilhã/Portugal. Professor associado do Departamento de Comunicação Social e do Programa de Pós-Graduação em Comunicação da Universidade Federal de Pernambuco. E-mail: hclrocha@gmail.com
}

\section{Revista ALTERJOR}

Grupo de Estudos Alterjor: Jornalismo Popular e Alternativo (ECA-USP)

Ano 12 - Volume 01 - Edição 25 - Janeiro-Junho de 2022

Av. Professor Lúcio Martins Rodrigues, 443, Cidade Universitária, São Paulo, CEP: 05508-020 


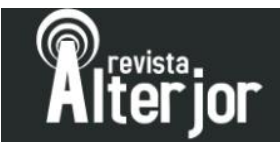

\section{Introdução: a análise crítica do discurso como ação política}

Este artigo procede a uma análise crítica do discurso e concebe o discurso que se pretende jornalístico sobre política como uma forma de agir nas plataformas digitais e online de comunicação, isso porque não há mais sentido em se proceder a uma antiga distinção de um mundo "real" e "virtual" (uma vez que ambos coexistem e se retroalimentam o tempo todo); agora vive-se uma "virtualidade real" ao qual se referia Castells (1999), para tratar de nova forma de sociedade, caracterizada por cultura construída a partir de um sistema de mídia onipresente, interligado e altamente diversificado ${ }^{5}$.

Assim o discurso, do particular ao público, é considerado aqui uma prática social usada através da linguagem para legitimar posições, ideologias e ações sociais. Para a análise de discurso de vertente anglo-saxônica, é importante pesquisar por que e como alguns significados se tornam padrões em determinados contextos e por que e como outros significados se tornam marginalizados.

Neste caso, a análise crítica de discurso neste trabalho foi feita levando em consideração estudos de Teun A. van Dijk (2016, 2012, 2010, 1997), Norman Fairclough, (1989) e Rosalind Gill (2002). Para van Dijk (1997, p. 20) ${ }^{6}$, o discurso político é uma ação política: "esse discurso é visto como uma forma de ação política e como parte do processo político". Ainda segundo o autor (1997), embora essa forma de agir tenha sido demonstrada na maioria das abordagens sociais do discurso, para a interação ou diálogo falado, é óbvio que também os textos escritos, ou melhor, escrever

\footnotetext{
${ }^{5}$ Essa nova forma de sociedade, para além da cultura midiática (virtualidade real), seria caracterizada também pela globalização das atividades econômicas decisivas do ponto de vista estratégico; por sua forma de organização em redes; pela flexibilidade e instabilidade do emprego e a individualização da mão-de-obra; e pela transformação das bases materiais da vida - o tempo e o espaço - mediante a criação de um espaço de fluxos e de um tempo intemporal como expressões das atividades e elites dominantes.

${ }^{6}$ Tradução livre da própria autora, a partir do trecho: Alter this initial positioning of discourse in the realm of politics, we may now turn to a closer look at political discourse itself. It has been emphasized that both in politics and in political cience, such discourse is prímarily seen as a form of political action, and as pan of the political process. Such a view is perfectly compatible with the dominant paradigm in most social approaches to discourse, viz., that discourse is a form of social action and interaction (Atkinson \& Heritage 1984; Boden \& Zimmennan 1991; van Dijk 1985). Although this has especially been shown to hold for spoken interaction or dialogue, it is obvious that also written texts, or rather writing texts, are a form of social and political action. Textual (written, printed, computer) communication may not be face-to-face, but therefore no less a form of action and interaction (DIJK, 1997, p. 20).
}

Revista ALTERJOR

Grupo de Estudos Alterjor: Jornalismo Popular e Alternativo (ECA-USP)

Ano 12 - Volume 01 - Edição 25 - Janeiro-Junho de 2022

Av. Professor Lúcio Martins Rodrigues, 443, Cidade Universitária, São Paulo, CEP: 05508-020 


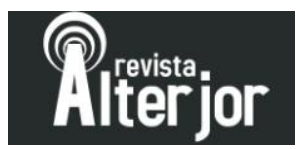

textos (lugar de inserção do jornalista), são uma forma de ação social e política. A comunicação textual, portanto, seja ela mediada ou não por computadores, pode não ser face a face, mas também não é uma forma menor ou menos importante de ação e interação. É, portanto, neste contexto que inserem as plataformas digitais, conectadas pela Internet (rede mundial de computadores) como lugares específicos e cada vez mais centrais de produção e circulação de discursos políticos travestidos de informação jornalística ou que se pretenda jornalística.

Outrossim, nas palavras de Norman Fairclough, (1989, p. 24 e 25) ${ }^{7}$, a concepção de discurso como ação se relaciona diretamente à ideia de linguagem como forma prática. Dessa forma, para ele (1989), fazer análise de discurso sob uma perspectiva crítica seria, portanto, investigar as incompletudes dos processos de produção e de interpretação de tais discursos, sem ignorar a maneira pela qual eles são determinados socialmente e compreender a linguagem como prática social "que é condicionada por outras partes da sociedade". Dessa forma, produção e interpretação de discursos são sociais porque têm origens sociais, no sentido de que eles são forjados socialmente e sua natureza depende das relações sociais e das lutas das quais foram gerados - assim também como foram socialmente transmitidos e, em nossa sociedade, distribuídos de forma desigual. Ao internalizar isso, as pessoas se engajam em suas práticas sociais, incluindo o discurso.

E, conforme Gill (2002, p. 247), para pensar a análise de discurso é necessário que se faça levando em consideração quatro temas principais: "uma preocupação com o discurso em si mesmo; uma visão da linguagem como construtiva (criadora) e

\footnotetext{
${ }^{7}$ Tradução livre da própria autora, a partir do trecho: However, no account of the processes of production and interpretation can be complete which ignores the way in which they are socially determined, which brings us to the third implication of seeing language as social practice: that it is conditioned by other, non-linguistic, parts of Society. The members resources (MR) which people draw upon to produce and interpret texts are cognitive in the sense that they are in people's heads, but they are social in the sense that they have social origins - they are socially generated, and their nature is dependent on the social relations and struggles out of which they were generated - as well as being socially transmitted and, in our Society, unequally distributed. People internalize what is socially produced and made available to them, and use this internalized MR to engage in their social practice, including discourse. This gives the forces which shape societies a vitally important foothold in the individual psyche, though as we shall see, the of this foothold depends on it being not generally apparent. Moreover, it is not the nature of these resources that is Socially determmed, but also the conditions of their use - for instance, different cognitive strategies are conventionally expected when someone is reading a poem on the one hand, and a magazine advertisement on the other. It is important to take account of such differences when analysing discourse from a critical perspective (FAIRCLOUGH, 1989, p. 24 e 25).
}

\section{Revista ALTERJOR}

Grupo de Estudos Alterjor: Jornalismo Popular e Alternativo (ECA-USP)

Ano 12 - Volume 01 - Edição 25 - Janeiro-Junho de 2022

Av. Professor Lúcio Martins Rodrigues, 443, Cidade Universitária, São Paulo, CEP: 05508-020 


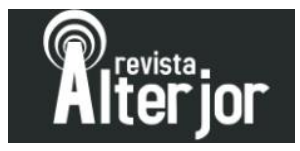

construída; uma ênfase no discurso como uma forma de ação; e uma convicção na organização retórica do discurso".

Assim considerado, este artigo apresenta uma análise discursiva do que se pretende jornalismo político que se forja nos maiores blogs (auto intitulados sites jornalísticos) da cidade de Pau dos Ferros - polo da região sertaneja, interior do Rio Grande do Norte / Brasil: "Política Pau-ferrense, a notícia passada a limpo", escrito por Clodoeudes Fernandes de Queiroz, radialista e acadêmico em Comunicação Social / Jornalismo pela Universidade do Estado do Rio Grande do Norte - $\mathrm{UERN}^{8}$, com o endereço eletrônico http://politicapauferrense.blogspot.com.br ${ }^{9}$; e Blog do Capote, escrito por Raimundo Nilzemar Almeida ou, simplesmente, Mazinho Capote, graduado em Letras pela UERN e funcionário da VI Unidade Regional de Saúde Pública - VI USARP, com o endereço em http://www.blogdocapote.com $/{ }^{10}$. Vale ressaltar que esses dois blogs têm perfis correspondentes no Facebook, mas não como páginas oficiais dos blogs e sim como perfis pessoais de seus blogueiros. Geralmente, eles tendem a se utilizar do texto que se assemelha ao noticioso para privilegiarem uma das lideranças políticas de Pau dos Ferros. O Política Pau-ferrense faz a linha mais de centro e apoiou Leonardo Rêgo - ex-prefeito por três mandatos; o Blog do Capote, com um tom mais pessoal, apoiou a oposição liderada pelo médico Nilton Figueiredo (ex-prefeito da cidade por três mandatos, 1989-1992; 1997-2000; 2001-2004). Anteriormente a oposição política na cidade se fazia entre Nilton Figueiredo em aliança com Maria Rêgo (mãe de Fabrício Torquato, ex-prefeito também) de um lado e Getúlio Rêgo (deputado estadual com maior número de mandatos eletivos consecutivos na história do Brasil e pai de Leonardo Rego - ex e atual prefeito da cidade, em seu terceiro mandato), do outro. Com o desenrolar das alianças políticas a cada eleição, a disputa pelo poder executivo da cidade passou a ser dado entre Leonardo Rego e Fabrício Torquato de um lado e Nilton Figueiredo, do outro. No pleito de 2014 para o governo do Estado do RN, houve mais uma reconfiguração: Fabrício Torquato, ex vice-prefeito e eleito sucessor de

\footnotetext{
${ }^{8}$ Informação retirada da própria página em 11 de maio de 2020: http://politicapauferrense.blogspot.com/p/blog-page.html.

${ }^{9}$ Informação aberta ao público em seu próprio blog e suas redes sociais digitais.

${ }^{10}$ Informação aberta ao público em seu próprio blog e suas redes sociais digitais.
} 
Leonardo Rêgo, rompe com este último e se alinha a Nilton Figueiredo. Findo o mandato de Fabrício Torquato (em 2016), ele perde as eleições, vira oposição e Leonardo Rego sai do papel de oposição para virar situação e então prefeito da cidade de Pau dos Ferros/RN, com mandato até o fim de 2020. 2021, a oposição (liderada por Nilton Figueiredo e novamente Maria Rego - mãe de Fabrício Torquarto, vira mais uma vez situação). Agora uma nova personagem é inserida nessa história, a candidata do grupo é Mariana Almeida que vence as eleições com a representação social de ser a primeira mulher LGBTQIA+ a assumir o executivo municipal para o mandato de 2021 a 2024. Assim também seguiu as linhas editoriais dos blogs, ambos já mudaram de lado explicitamente algumas vezes.

\section{Alguns procedimentos metodológicos de coleta e categorização de dados para uma análise discursiva}

Para o recorte temporal de análise neste estudo, procedemos a coleta de dados a qual foi feita durante os meses de agosto, setembro e outubro de 2016, vésperas que antecedem às eleições municipais ${ }^{11}$ (para eleger prefeito e vereadores) no Brasil e momento em que o acirramento político mais se faz presente nas localidades regionais interioranas, muito mais do que o período eleitoral para presidente da República, Governadores dos Estados, Deputados e Senadores. Dessa forma, foi feito um monitoramento em forma de E-clipping ${ }^{12}$ de todo o conteúdo noticioso sobre política publicado nos blogs específicos de política e mais acessados da cidade de Pau dos Ferros / RN: Blog do Capote (http://www.blogdocapote.com/) e Política Pau-ferrense (http://politicapauferrense.blogspot.com.br/) com o conteúdo replicado nos Sites de Redes Sociais - $\quad$ SRS, especificamente no Facebook: https://www.facebook.com/mazinho.capote

https://www.facebook.com/clodoeudes.fernandes, consecutivamente.

\footnotetext{
${ }^{11}$ As eleições aconteceram no dia 02 de outubro de 2016.

${ }^{12}$ Abreviação do termo eletronic clipping, variação atual do termo clipping que vem da língua inglesa, e define o processo de selecionar notícias e produtos midiáticos em jornais, revistas, sites e outros meios de comunicação, para resultar num apanhado de recortes sobre assuntos de total interesse de quem os coleciona. O E-clipping diz respeito ao clipping feito eletronicamente.
}

\section{Revista ALTERJOR}

Grupo de Estudos Alterjor: Jornalismo Popular e Alternativo (ECA-USP)

Ano 12 - Volume 01 - Edição 25 - Janeiro-Junho de 2022 


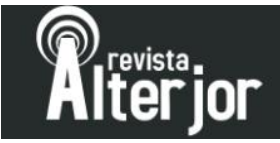

Uma vez, iniciado o E-clipping, foram coletados neste período o total de 369 notícias, divididas inicialmente seguindo as plataformas digitais e online de publicação: blog e Facebook, de acordo com a Tabela 01, mostrada a seguir:

Tabela 01: Total de notícias coletadas.

\begin{tabular}{c|c|c|c|c}
\hline & Blog & Facebook & Total & Total Geral \\
\hline Blog do Capote & 77 & 102 & 179 & 369 \\
\hline $\begin{array}{c}\text { Política Pau- } \\
\text { ferrense }\end{array}$ & 86 & 104 & 190 & \\
\hline
\end{tabular}

Fonte: Elaborada pelos próprios autores, 2017.

Deste universo de 369 notícias, mostradas na Tabela 01, coletadas em três meses, foram escolhidos alguns dias para formar uma semana aleatória a fim de se constituir o material amostral por representatividade a ser analisado. Assim, ficou estabelecido que seriam analisadas aleatoriamente as notícias publicadas em três dias da semana do mês de agosto, três dias da semana do mês de setembro e 1 dia da semana do mês de outubro (a semana que antecedeu a eleição), como mostram as Tabelas 02, 03 e 04:

Tabela 02: Semana aleatória: amostragem por representatividade simples para análise - Blog do Capote.

\begin{tabular}{c|c|c|c|c}
\hline Blog do Capote & Blog & Facebook & Total & Total Geral \\
\hline $\begin{array}{c}\text { Segunda-feira } \\
(01 / 08 / 2016)\end{array}$ & 3 & 2 & 5 & \multirow{2}{*}{46} \\
\cline { 1 - 3 } $\begin{array}{c}\text { Terça-feira } \\
(02 / 08 / 2016)\end{array}$ & 4 & 4 & 8 & \\
\cline { 1 - 3 } $\begin{array}{c}\text { Quarta-feira } \\
(17 / 08 / 2016)\end{array}$ & 3 & 4 & 7 & \\
\hline $\begin{array}{c}\text { Quinta-feira } \\
(15 / 09 / 2016)\end{array}$ & 2 & 3 & 5 & \\
\hline
\end{tabular}

\section{Revista ALTERJOR}

Grupo de Estudos Alterjor: Jornalismo Popular e Alternativo (ECA-USP)

Ano 12 - Volume 01 - Edição 25 - Janeiro-Junho de 2022 


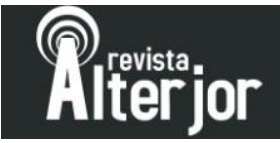

\begin{tabular}{c|c|c|c|}
\hline $\begin{array}{c}\text { Sexta-feira } \\
(16 / 09 / 2016)\end{array}$ & 1 & 1 & 2 \\
\hline $\begin{array}{c}\text { Sábado } \\
(01 / 10 / 2016)\end{array}$ & 1 & 9 & 10 \\
\hline $\begin{array}{c}\text { Domingo } \\
(11 / 09 / 2016)\end{array}$ & 1 & 8 & 9 \\
\hline
\end{tabular}

Fonte: Elaborada pelos próprios autores, 2017.

Tabela 03: Semana aleatória: amostragem por representatividade para análise Política Pau-ferrense.

\begin{tabular}{|c|c|c|c|c|}
\hline $\begin{array}{c}\text { Política Pau- } \\
\text { ferrense }\end{array}$ & Blog & Facebook & Total & Total Geral \\
\hline $\begin{array}{c}\text { Segunda-feira } \\
(01 / 08 / 2016)\end{array}$ & 7 & 8 & 15 & \multirow{7}{*}{63} \\
\hline $\begin{array}{c}\text { Terça-feira } \\
(02 / 08 / 2016)\end{array}$ & 8 & 9 & 17 & \\
\hline $\begin{array}{l}\text { Quarta-feira } \\
(17 / 08 / 2016)\end{array}$ & 4 & 4 & 8 & \\
\hline $\begin{array}{l}\text { Quinta-feira } \\
(15 / 09 / 2016)\end{array}$ & 0 & 1 & 1 & \\
\hline $\begin{array}{c}\text { Sexta-feira } \\
(16 / 09 / 2016)\end{array}$ & 6 & 6 & 12 & \\
\hline $\begin{array}{c}\text { Sábado } \\
(01 / 10 / 2016)\end{array}$ & 3 & 3 & 6 & \\
\hline $\begin{array}{c}\text { Domingo } \\
(11 / 09 / 2016)\end{array}$ & 2 & 2 & 4 & \\
\hline
\end{tabular}

Fonte: Elaborada pelos próprios autores, 2017.

De acordo com as Tabelas 02 e 03, o total de notícias analisadas equivalem a 109 textos distribuídos nas publicações dos dois Blogs e suas respectivas páginas no SRS Facebook.

\section{Revista ALTERJOR}

Grupo de Estudos Alterjor: Jornalismo Popular e Alternativo (ECA-USP)

Ano 12 - Volume 01 - Edição 25 - Janeiro-Junho de 2022 


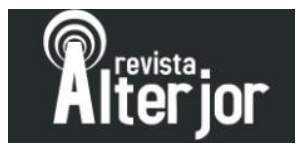

Feito isso, seguiu-se a um segundo momento procedimental, o da categorização das notícias, para enfim se realizar a análise crítica de discurso, a qual se fundamentou nas pesquisas propostas por Rosalind Gill (2002) que sugere codificar os textos (no caso desta pesquisa, notícias sobre política em plataformas digitais e online) segundo os objetivos (realçar, ou selecionar, todas as ocasiões em que se evidencia a razão de ser da categoria).

Gill (2002, p. 254) ensina que a categorização (codificação) deve ser feita da maneira mais abrangente possível, de tal modo que todas as instâncias limítrofes possam ser incluídas, em vez de serem deixadas fora. Codificação é uma maneira de organizar as categorias de interesse. Pode-se começar por separar as transcrições em diferentes tipos de explicações. "É importante notar que os indivíduos podem ser levados por diferentes explicações, ou combiná-las, e que o interesse do analista de discurso não é as atitudes individuais, mas a construção cultural”. Assim sendo, o conteúdo foi reorganizado em cinco categorias que emergiram a posteriori da coleta, seguindo as temáticas emergentes e que tendiam a repetição (uma espécie de padrão de dados), levando sempre em consideração os objetivos, a fim de que os dados recombinados se tornassem melhor apresentáveis para a compreensão e análise.

As cinco categorias de análise foram definidas tentando responder / complementar o pensamento de "todas as ocasiões em que..." (o alinhamento proposto por Gill (2002)): 1 - O discurso evidencia o expurgo do não-eu; 2 - O discurso evidencia promoção da boa imagem; 3 - O discurso se faz através de conotações; 4 - O discurso de Informações locais exprime um contexto global; e 5 - O discurso não dito.

Para efeitos deste artigo, considerando que o estudo tem resultados e discussões muito mais abrangentes do que caberia em um espaço destinado a um artigo, escolheuse aqui tratar analiticamente de apenas uma das categorias - a com maior número de inserção/publicação de textos noticiosos: a de número 1 - $\mathrm{O}$ discurso que evidencia o expurgo do não-eu.

A classificação das notícias seguiu esta definição para os textos que noticiavam a política com a intenção de depreciar alguém, deixando explícito quem é esse não-eu, o outro que se evidencia ideologicamente diferente, "alheio a mim" e se distingue de uma 


\section{Preitior}

forma tão belicosa que se torna inimigo, geralmente materializado nos candidatos políticos adversários a quem a linha editorial das plataformas digitais e online se faz opositora.

Só então foi possível a análise crítica de discurso, a partir da qual é destacada a interação entre este discurso e a ação política de expurgar o não-eu no jogo democrático - fato que acaba tangenciando pretensões patrimonialistas - conceito desenvolvido por diversos autores, mas que aqui tem o cerne no entendimento de Max Weber (1982; 1999), atualizado por pesquisadores brasileiros como Sérgio Buarque de Holanda (2011), Raymundo Faoro (2001) e Jessé de Souza (2016).

\section{Analisando os dados: o discurso que se pretende jornalístico sobre política e o expurgo do não-eu}

Expurgar o não-eu, o que é diferente, o que se distingue do "meu eu" na ideologia que forja as respectivas práticas sociais (e vice-versa), constitui-se um recurso bastante usado em boa parte do jornalismo feito quando se trata de política. Para a formação desse discurso, os pretensos jornalistas têm uma preocupação singular: elaborar um alvo para suas críticas, tornar claro porque esse repúdio é necessário, pois seu alvo é precisamente "um tipo de político". Não é, contudo, todos os políticos e formas de se fazer política que os blogs / perfis do Facebook estudados aqui condenava, mas um tipo especifico de "Gestor de meia tigela e traidor".

Esse texto, entre aspas do parágrafo anterior, foi parte do título da matéria, publicada no Blog do Capote, no dia primeiro de agosto de 2016, "São Miguel-RN: Na Convenção, que homologou chapa Zé Gaudêncio/Salismar, deputado Galeno disse que “o município parou porque o gestor é de meia tigela e traidor". A notícia completa, é a que segue:

Com a presença de lideranças da política estadual, como o governador Robinson Faria (PSD), o prefeito de Pau dos Ferros, Fabrício Torquato, de José da Penha, Antônio Dólar, Dagoberto Bessa de Severiano Melo, Klébia Bessa (Tabuleiro Grande), Antônio Dólar (José da Penha), Alberone Néri (Encanto) Carlos Jácome (Dr. Severiano) e Jessé (Riacho de Santana) a convenção partidária do 
PSD, em São Miguel, deu o pontapé inicial na pré-campanha a prefeito e vice de Zé Gaudêncio (PSD) e Salismar Correia (PHS).

Além do PSD e PHS, a Coligação denominada de 'O Trabalho vai Voltar", é formada por mais sete siglas: DEM, PV, PPS, PTN, PHS, PCdoB e PTdoB.

Capitaneada pelo deputado estadual Galeno Torquato (PSD), que já foi prefeito de São Miguel por dois mandatos, a convenção lotou as dependências do ginásio 'Torquatão' se estendendo das 10 horas da manhã até às $15 \mathrm{~h}$ desse domingo, 31 de julho.

Para o deputado, a pré-candidatura do seu irmão, o arquiteto José Gaudêncio Torquato, representa a retomada do desenvolvimento do município, que é localizado no Alto Oeste potiguar. Milhares de micaelenses participaram do evento.

"A administração pública de São Miguel é um marasmo. A saúde está enferma. A educação é um descaso. As ruas estão esburacadas. Estou fazendo o meu papel de deputado, mas os recursos que chegam para o município não estão sendo bem aplicados", apontou o deputado, acrescentando que "São Miguel parou porque não ficou um administrador; ficou um traidor".

Além de condenar o casamento de cobra d'água com jacaré, referindose ao acordão feito pelo grupo governista com adversários de 2012, que fizeram de tudo para barrar a candidatura do atual gestor naquela época, Galeno também disse que "o atual prefeito é de meia tigela, preguiçoso, desleixado e que está acabando com tudo que nós fizemos em São Miguel”.

Já o governador Robinson Faria comentou que ficou impressionado com o tamanho da participação popular na convenção, que, segundo disse, foi a maior que ele já presenciou em suas andanças pelo estado neste início de campanha.

Adotando um discurso propositivo, Zé Gaudêncio convocou a militância para ir às ruas e se manter vigilante. Ele anunciou que a partir de agosto visitará cada casa da cidade, mostrando as realizações de sua administração. "Vamos mostrar aos micaelenses todos os descasos da atual administração e mostrar que é possível mudar, que é possível colocar São Miguel novamente no rumo certo", pontuou Zé Gaudêncio, destacando que, ao ser abordado por uma senhora numa comunidade rural sobre seu Plano de Governo, respondeu que "meu Plano de Governo é botar pra funcionar tudo o que está parado em São Miguel!" (CAPOTE, 2016, online).

Para além da necessidade de personificar o texto, dando destaque a cada nome de lideranças políticas da região sertaneja do RN, o Alto Oeste Potiguar, mesmo para noticiar o evento de Convenção e registro de candidaturas das pessoas para as eleições que ocorreria em outubro, o redator inicia seu discurso depreciando os adversários políticos já no título.

\section{Revista ALTERJOR}

Grupo de Estudos Alterjor: Jornalismo Popular e Alternativo (ECA-USP)

Ano 12 - Volume 01 - Edição 25 - Janeiro-Junho de 2022 


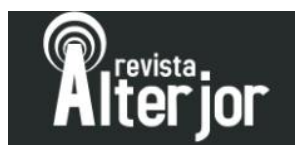

No decorrer do texto, o blogueiro dá voz primeiro a um deputado estadual (ao qual ele incumbe o papel de capitanear, de chefia...) e não aos candidatos que deveriam estar pleiteando votos. Nas palavras do deputado, adjetivos para depreciar a gestão atual como marasmo, saúde enferma, educação em descaso e ruas esburacadas são estratégias de expurgação do não-eu que se somam à ideia da não aplicabilidade bem feita dos recursos públicos que até então teriam chegado à prefeitura e de que tudo isso tinha uma única causa: a cidade não teria um administrador (função social idealizada que ele dá à figura do prefeito), mas um traidor, um prefeito que é de meia tigela (expressão repetida no título e no corpo da matéria), preguiçoso, desleixado. Aqui, macula-se com adjetivos e expressões semelhantes não apenas uma gestão, mas a própria pessoa física e particular.

É interessante perceber que, mesmo majoritariamente enquadrada nesta categoria, não significa dizer que outras formas de leituras, como a "Promoção da boa imagem" (neste caso, autopromoção) ou "O discurso não dito" possam ser pensadas em conjunto, como quando ele dá voz ao deputado que diz "estou fazendo meu papel de deputado"; ou seja, não é todo político que deve ser expurgado, o próprio deputado Galeno Torquato seria uma exceção, seria um bom político. Ou quando ele se refere "à retomada do desenvolvimento do município", ao fato do atual prefeito "está acabando com tudo que nós fizemos em São Miguel”, ou quando o jornalista dá voz ao então governador do Estado do Rio Grande do Norte - Robison Faria para relatar o tamanho da participação popular na convenção, que seria "a maior que ele já presenciou"; deixando nas entre linhas que a atual gestão tinha deixado de fazer a cidade crescer, que o próprio deputado e o grupo político dele já fizeram muito pela cidade de São Miguel / $\mathrm{RN}$ e que a campanha seria fácil de ganhar, porque o governador conheceria o Estado, já deveria ter participado de muitos eventos semelhantes e teria, então, autoridade para dizer que o candidato teria muitos votos ao ponto de vencer o pleito.

É interessante perceber que o discurso que se pretende jornalístico sobre política neste caso não se pauta na divulgação de fatos políticos em si, mas prioritariamente em cima da citação de falas de atores políticos considerados líderes locais e regionais e assim se faz também enquanto ação política. Não foi noticiado, por exemplo, o ritual da

\section{Revista ALTERJOR}

Grupo de Estudos Alterjor: Jornalismo Popular e Alternativo (ECA-USP)

Ano 12 - Volume 01 - Edição 25 - Janeiro-Junho de 2022

Av. Professor Lúcio Martins Rodrigues, 443, Cidade Universitária, São Paulo, CEP: 05508-020 


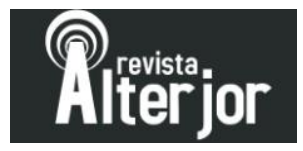

Convenção, explicando que processo político é este e qual a importância dele para o fortalecimento da democracia. A fala do candidato às eleições municipais 2016 foi deixada por último, com menos destaque na desconstrução da oposição. Quem deveria falar mal do outro, seriam os apoiadores. O próprio candidato deve fazer "um discurso propositivo", "convocar a militância", promover a valorização de cada casa (sentido da família) através de visitas e a possibilidade de "colocar São Miguel novamente no rumo certo" ao elegê-lo.

Há uma apropriação dessas falas por parte do redator que mescla com sua própria linha editorial de apoio ou oposição política e constrói o seu próprio discurso de expurgo do não-eu, através de escolhas de recursos linguísticos de depreciação; por exemplo quando ele se utiliza de palavras como "condenar" e "acordão" (palavra usualmente colocada em circulação popular para deslegitimar as alianças políticas do adversário, para dizer que tais alianças são, na verdade, negócios financeiros escusos). Assim o patrimonialismo (a confusão entre público e privado) se apresenta aqui como o processo de não separação da pessoa do jornalista (ou pretenso jornalista) e da pessoa do eleitor. Escritor do blog que pretende a credibilidade jornalística e eleitor político se fundem e o discurso personificado deste último influencia diretamente na escrita do discurso do primeiro (e vice-versa), tornando algo que deveria ser suprapartidário (ou pelo menos subjetivamente responsável com a linha editorial explícita) visivelmente partidário, eleitoreiro e opaco (quanto à motivação democrática).

Também é possível perceber resquícios da relação genética entre o patriarcalismo e o patrimonialismo ${ }^{13}$, quando o poder de falar primeiro e com maior importância e destaque é dado pelo jornalista a atores do sexo masculino e considerados líderes, chefes, pais do grupo político, mesmo quando essa "estrutura de dominação patriarcal" se faz descentralizada, como previu Weber (1999), mediante a cessão de espaço de fala para líderes menores, com menos eleitores ou pertencentes a cidades e regiões com menos votos e / ou apoio de outros políticos. Ainda assim a figura do pai poder dispor em primeira instância do discurso ao seu bel prazer, sem limites inclusive

\footnotetext{
${ }^{13}$ Conceito previsto em Sérgio Buarque de Holanda e Raymundo Faoro, aqui no Brasil, por exemplo; e ressignificado em Jessé de Souza, mas também pensado, preliminarmente, por Weber a partir da ideia de dominação (SENA, 2017).
}

Revista ALTERJOR

Grupo de Estudos Alterjor: Jornalismo Popular e Alternativo (ECA-USP)

Ano 12 - Volume 01 - Edição 25 - Janeiro-Junho de 2022

Av. Professor Lúcio Martins Rodrigues, 443, Cidade Universitária, São Paulo, CEP: 05508-020 


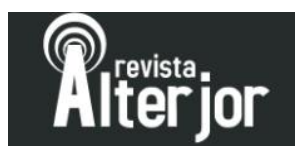

para depreciar a figura particular e não pública do outro, demonstra uma atualização do patrimonialismo que é exercido através do discurso jornalístico.

Além disso, é imprescindível observar esse patrimonialismo como um termo essencialmente político, que se utiliza de estratégias para lograr êxito na dominação de forma legítima. Aqui o discurso do blogueiro, ao forjar a figura do político, ultrapassa os limites da dominação Legal - burocrática (geralmente presente no poder público estatal das sociedades democráticas), para se legitimar também através da fusão dos processos carismático e tradicional. No expurgo da gestão do opositor, alinha-se e se ratifica o expurgo à pessoa privada do opositor, enquanto se promove a boa imagem de quem o Blog apoia.

Aqui destaca-se os pensamentos de ideologia relacionadas a poder, por van Dijk (2010). Mais especificamente, quando o autor (2010) aborda o conceito de "quadrado ideológico" para demonstrar como as pessoas tendem a enfatizar as coisas boas delas e dar visibilidade as coisas ruins dos outros; ao mesmo tempo que tendem a ocultar coisas ruins delas e ocultar as coisas boas dos outros. É uma releitura social do princípio patrimonialista que se baseia no discurso: aos meus, tudo; aos outros, a lei ${ }^{14}$.

Ainda seguindo esse contexto, no dia 17 de agosto, também no Blog do Capote foi publicado o seguinte texto, com a chamada "São Francisco do Oeste-RN: Funcionário do candidato a prefeito, Luzimar Porfírio, declara apoio a Chiquinho Lôbo e diz que está sendo perseguido":

O funcionário João Paulo da Silva, da empresa POEST - Indústria e Comércio Ltda, com sede em São Francisco do Oeste-RN, usou seu perfil no facebook para denunciar que está sendo perseguido por 'gerentes', colegas de trabalho e pelo próprio dono, empresário Luzimar Porfírio (PSD), que é candidato a prefeito naquele município. Segundo 'Jotapê Silva', como é mais conhecido, "desde quando resolvi defender o lado da situação atual de nosso município, apoiando os candidatos Chiquinho Lobo e Gessé Freitas, o mundo caiu sobre mim! Estou vivendo dias de horrores partindo de gerentes, funcionários e o próprio dono", escreveu em tom de desabafo.

JP também declarou na sua postagem "que na própria empresa há, aproximadamente, umas 20 pessoas que não votam" no candidato Luzimar Porfírio, que é o dono.

\footnotetext{
${ }^{14}$ Frase reconfigurada e atribuída a Maquiavel: Aos amigos os favores; aos inimigos a lei.

Revista ALTERJOR

Grupo de Estudos Alterjor: Jornalismo Popular e Alternativo (ECA-USP)

Ano 12 - Volume 01 - Edição 25 - Janeiro-Junho de 2022 


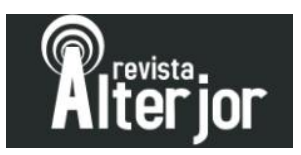

Ele ainda enumerou diversas situações de assédio moral que está vivendo no seu local de trabalho, inclusive que teve de comparecer ao serviço, mesmo comunicando que estava doente.

Jottapê, que também trabalha com publicidade, ainda disse que o sorriso de Luzimar Porfírio é falso e que ele ainda não desistiu de disputar a eleição deste ano porque "toda hora está sendo pressionado" para continuar.

E concluiu com uma pergunta. "Vejam, meus caros amigos e leitores, se realmente é isso que vocês querem: um homem desse na prefeitura de nosso município?" (CAPOTE, 2016, online)

Nesse texto, além de seguir o parâmetro de expurgar o qualquer um que não seja o eu (candidato apoiado pela página), tornando-o não só o adversário eleitoral, mas um inimigo político, através de citação de terceiros "o sorriso de Luzimar Porfírio é falso", o Blog do Capote optou por colocar em xeque a credibilidade do candidato que não era alinhado à linha editorial do Blog, dando voz a acusações de supostas ameaças e perseguições aos não eleitores da chapa, a qual contaria com trabalhos escusos (transformando o dia de seus opositores em “dias de horrores") de gerentes (nome usado entre aspas pelo redator) e outros empregados do empresário e candidato a prefeito da cidade de São Francisco do Oeste / RN. Assim, não foi dado à notícia o espaço para as múltiplas vozes envolvidas no fato, tampouco o direito de resposta à inculpação "das diversas situações de assédios morais". Ao dar publicidade ao questionamento no fim da matéria, sem dar espaço para o leitor e / ou eleitor refletir sobre outras projeções que não “o quão ruim pode ser 'um homem desse', ou seja, um homem capaz de ameaçar seus funcionários, como gestor de uma cidade; segue o mesmo propósito: detratar o opositor. Também quando Capote ${ }^{15}$ dá visibilidade ao relato do empregado que teria sofrido assédio moral na empresa em que candidato Luzimar Porfírio é dono, no qual é possível ler que o empresário não ganharia as eleições porque teria poucos votos fiéis a ele, pois nem os funcionários da empresa (como se isso fosse uma obrigação seguindo a lógica do patrimonialismo Legal - Burocrático) votaria nele: "na própria empresa há, aproximadamente, umas 20 pessoas que não votam".

Vale ressaltar o fato de que toda a fonte que determina a escrita da notícia é uma postagem num perfil pessoal do Facebook. Isso chama atenção para as novas e

${ }^{15} \mathrm{O}$ autor do Blog assina suas matérias com o nome de Mazinho Capote, como se este fosse, além do nome do blog, o seu sobrenome.

Revista ALTERJOR

Grupo de Estudos Alterjor: Jornalismo Popular e Alternativo (ECA-USP)

Ano 12 - Volume 01 - Edição 25 - Janeiro-Junho de 2022

Av. Professor Lúcio Martins Rodrigues, 443, Cidade Universitária, São Paulo, CEP: 05508-020 


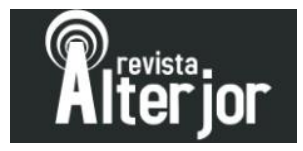

recorrentes transformações e desafios que o jornalismo vem enfrentando. Quando Mielniczuk (2003) conceitua jornalismo online como a pesquisa realizada em redes, onde as informações circulam em tempo real e cujo objetivo é a apuração jornalística (pesquisa de conteúdos, recolha de informações e contato de fontes), esse mesmo termo vai - ora de encontro ao, ora ao encontro do - pretenso jornalismo feito pelo Blog do Capote. Ao mesmo tempo que ele se serve de informações colhidas na rede, falta a ele a reponsabilidade (ou o querer) de apuração, de checar se esses outros 20 funcionários não votariam no candidato Luzimar Porfírio, se este, seu gerente ou demais funcionários da empresa teriam alguma coisa a dizer sobre as acusações, por exemplo.

Outro fato é que, mesmo o jornalismo online tendo linguagens e formações próprias, distintas de outros meios como a TV, o rádio e o impresso (CANAVILHAS, 2015; SERRA, 2003; MIELNICZUK, 2003), ainda assim o processo de escrita é dinâmico e depende da plataforma digital e online de publicação e propagação. Assim, o mesmo texto que é produzido para um blog não deveria ter as mesmas dimensões e formas linguísticas do que é produzido para ser publicado em uma página de Facebook. E isso parece ser esquecido ou não ser do conhecimento do blogueiro, uma vez que ele apenas transporta / replica a notícia / link da notícia de um sítio para o outro como pode ser visualizado na Figura 01:

FIGURA 01: Link da notícia no Facebook.

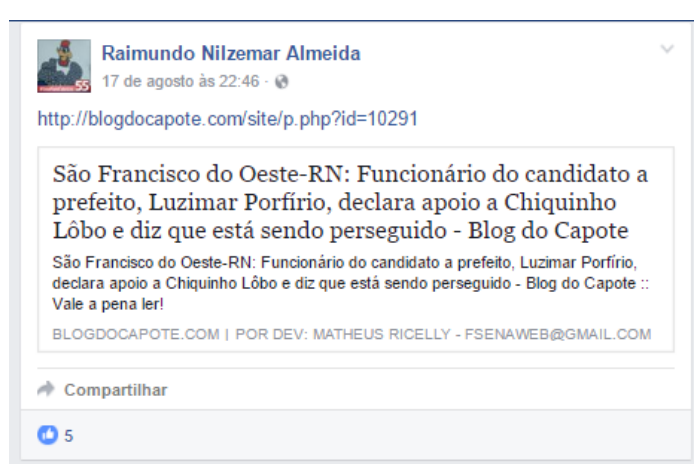

Fonte: Elaborado pelos autores (2016).

Uma percepção peculiar tida através desta Figura 01 é que, uma vez que o link da matéria seja publicado no Facebook, remetendo ao texto originalmente publicado no

\section{Revista ALTERJOR}

Grupo de Estudos Alterjor: Jornalismo Popular e Alternativo (ECA-USP)

Ano 12 - Volume 01 - Edição 25 - Janeiro-Junho de 2022 Av. Professor Lúcio Martins Rodrigues, 443, Cidade Universitária, São Paulo, CEP: 05508-020 


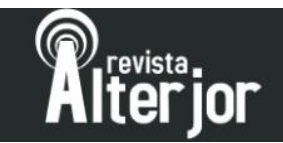

blog, mesmo que este não tenha tido nenhuma interatividade no blog, no Facebook ocorrem "likes / curtidas", "compartilhamentos", "comentários" e demais formas de engajamento. Em outras matérias, quando o reduto do assunto envolvia os candidatos a prefeito de Pau dos Ferros / RN, a interatividade se fazia de forma mais intensa, com um número bem superior de "curtidas, comentários e compartilhamentos", opções dadas pelo SRS Facebook.

Isso pode ser observado nas Figuras 02 e 3, quando o Blog do Capote anunciou, primeiro no Blog "Pau dos Ferros - RN: Deputado Getúlio Rêgo ameaçou blogueiro Mazinho Capote de morte" e depois replicou no Facebook. Ao observar que a interatividade tinha mais chances de ocorrer sobre aquele assunto no SRS, dado o número de curtidas, então, o blogueiro "requentou" o texto, apenas no Facebook, causando muito mais interatividade em torno do assunto, já que o personagem principal da notícia era o então deputado estadual Getúlio Rego, pai do ex-prefeito e então candidato novamente à prefeitura de Pau dos Ferros Leonardo Rego, a quem o blog explicitamente faz oposição. Expurgar o não-eu também poderia ser feito expurgando a família e os apoiadores do outro.

FIGURA 02: Matéria publicada com mais chances de interatividade.

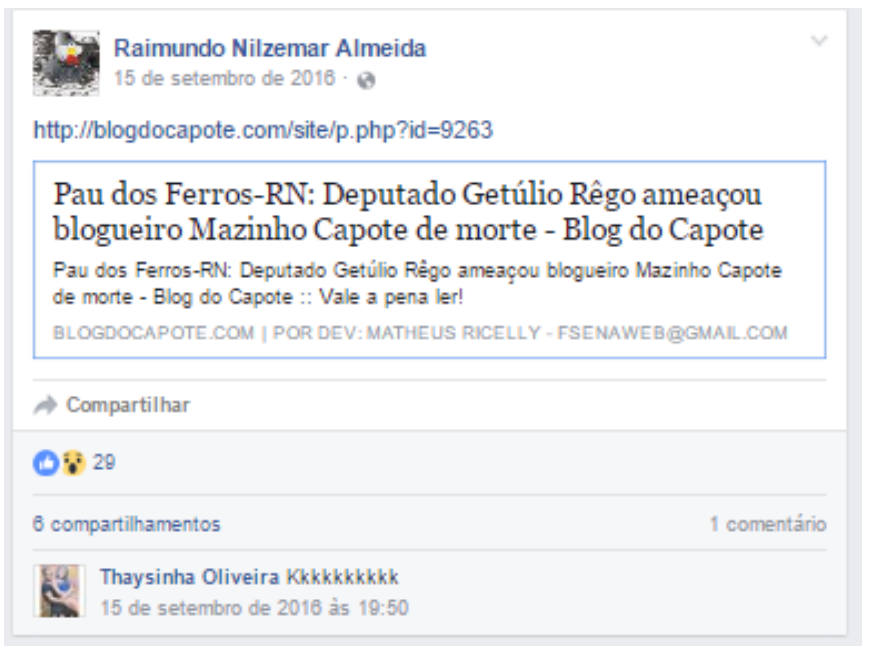

Fonte: Fonte: Elaborado pelos autores (2016). 


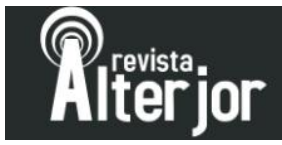

FIGURA 03: Matéria requentada para mais interatividade.

\section{Raimundo Nilzemar Almeida}

15 de setembro -

O deputado estadual HIPÓCRITA, Getúlio Rêgo (DEM), querendo figurar como um bom moço, alardeou aos quatros ventos que pediu

SEGURANÇA pra campanha eleitoral de Pau dos Ferros.

"Rapaz, criei vergonha"

Como é que você, falastrão, presta-se a um papel desses se AMEAÇOU MAZINHO CAPOTE DE MORTE?!?

Quem vive ameaçando o povo livre e soberano de Pau dos Ferros de morte é você, que se comporta como BANDIDO ou INTEGRANTE DO SINDICATO DO CRIME!!!

Xô, Satanás!

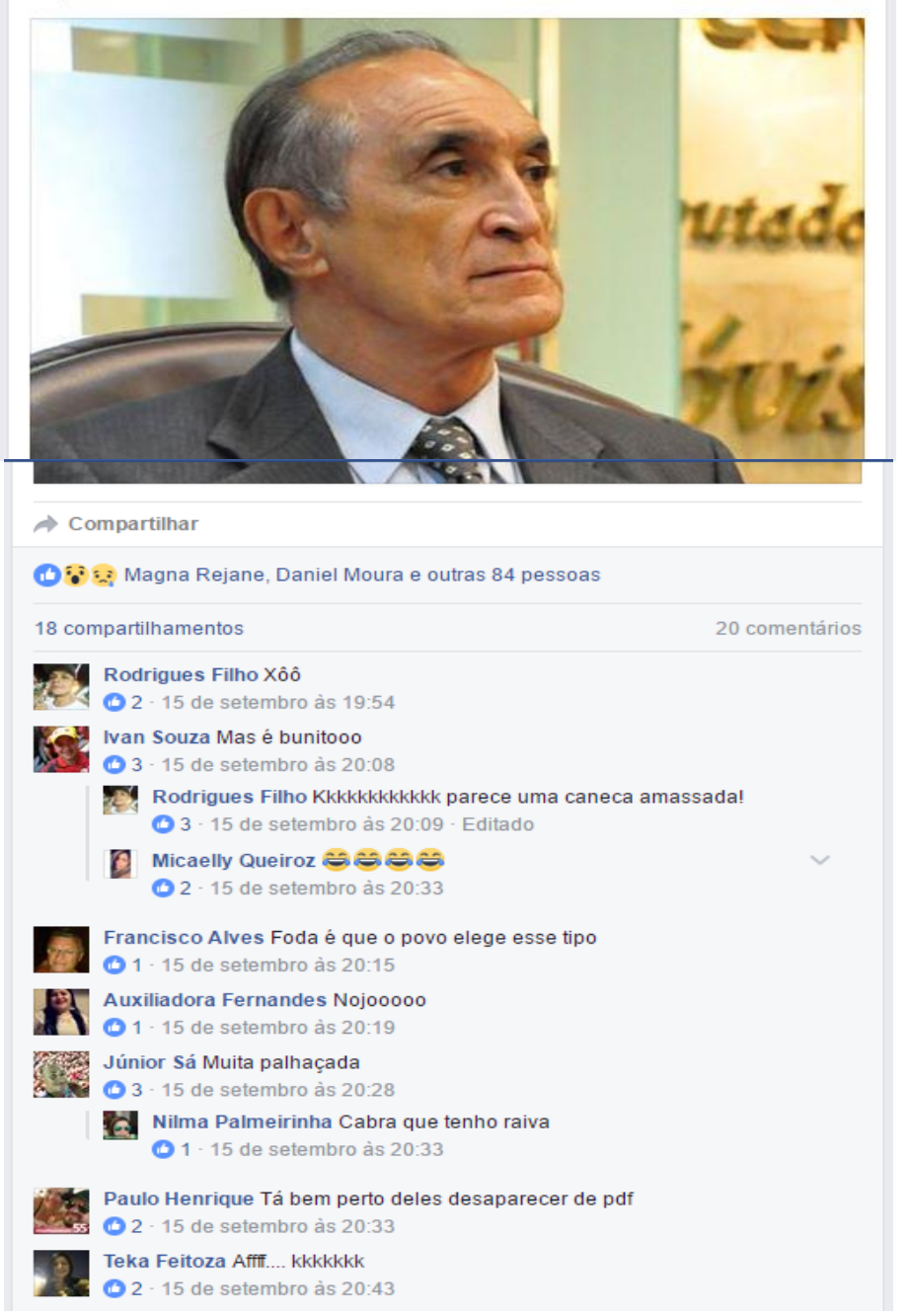

\section{Revista ALTERJOR}

Grupo de Estudos Alterjor: Jornalismo Popular e Alternativo (ECA-USP)

Ano 12 - Volume 01 - Edição 25 - Janeiro-Junho de 2022

Av. Professor Lúcio Martins Rodrigues, 443, Cidade Universitária, São Paulo, CEP: 05508-020 


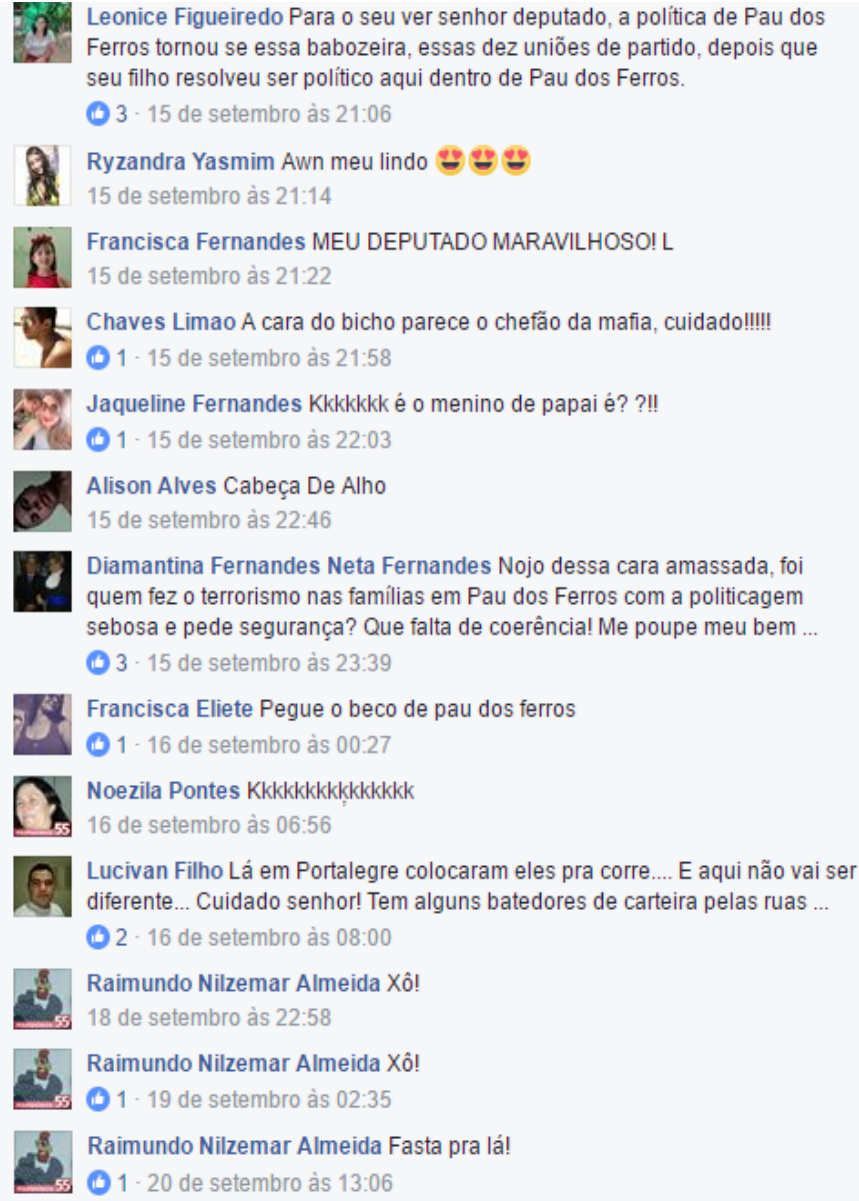

Fonte: Fonte: Elaborado pelos autores (2016).

A postagem rendeu mais de 80 curtidas, 18 compartilhamentos e 20 comentários, inclusive com respostas do próprio blogueiro aos comentários do post. Dessa forma, não é difícil perceber que expurgar o não-eu, em campanha eleitoral nos interiores, parece ser uma necessidade, especialmente nos Sites de Redes Sociais porque o alcance através da interatividade é muito maior que se isso fosse feito apenas no blog, e o acesso aos grandes meios de comunicação de alcance nacional e internacional é mais difícil e oneroso para atingir a um público especificamente local / regional. Mas ainda há a necessidade da postagem no blog, para dar o tom de ancoragem da credibilidade jornalística, adquirida um pouco mais pelos blogs que pelos Sites de Redes Sociais, visto que os primeiros foram aos poucos se legitimando como fonte alternativa e extra de conteúdo mais completos e detalhados, conforme analisou Paulo Serra (2015), ao

\section{Revista ALTERJOR}

Grupo de Estudos Alterjor: Jornalismo Popular e Alternativo (ECA-USP)

Ano 12 - Volume 01 - Edição 25 - Janeiro-Junho de 2022

Av. Professor Lúcio Martins Rodrigues, 443, Cidade Universitária, São Paulo, CEP: 05508-020 


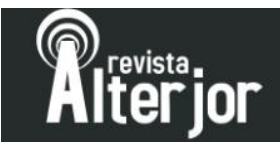

tratar da afirmação dos blogs como algo gradual e tendente à complementação, aprofundamento e, muitas vezes, retificação da informação das mídias noticiosas tradicionais - e, assim, de enriquecimento da informação publicamente disponível.

O Expurgo do não-eu ainda pode ser observado em matérias publicadas em 11 de setembro de 2016 no Facebook do Capote, com títulos como: "Faz 15 anos que Bin Laden mandou derrubar as Torres Gêmeas. Num passado mais recente, o ex-prefeito de Pau dos Ferros, novamente candidato, derrubou o Ginásio de Esportes Prof. João Faustino"; "O ex-prefeito, novamente candidato, com MEDO DE APOSTAR E PERDER feio, retirou TODO dinheiro que tinha nas poupanças da Caixa Econômica e no Banco do Brasil de Pau dos Ferros"; e "O ex-prefeito, novamente candidato, está numa situação tão complicada que nem apostar pode mais" (matéria requentada).

Detonar a gestão do ex-prefeito Leonardo Rego e comparar suas ações às de um homem internacionalmente acusado de terrorismo (Bin Laden); além de arrogar a ele as ideias de medo e de perda das eleições, foram estratégias corriqueiramente usadas durante todo o período eleitoral pelo blogueiro Mazinho Capote. O perfil do Facebook chegou a publicar imagens dos saldos bancários com as mais diversas insinuações sobre a sonegação e valorização de imóveis, como pode ser visto na Figura 04:

FIGURA 04: Publicação de saldos bancários.

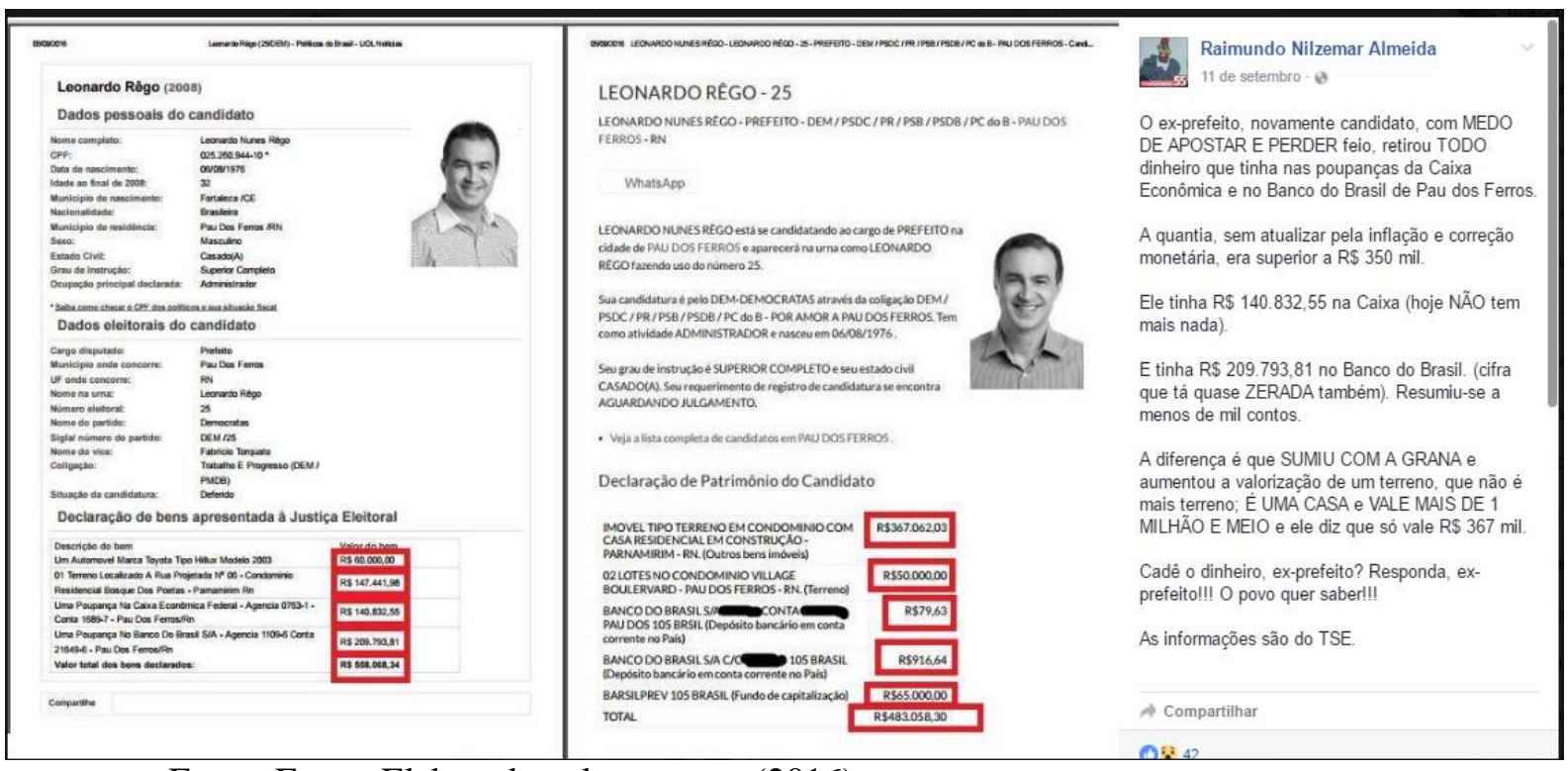

Fonte: Fonte: Elaborado pelos autores (2016).

Revista ALTERJOR

Grupo de Estudos Alterjor: Jornalismo Popular e Alternativo (ECA-USP)

Ano 12 - Volume 01 - Edição 25 - Janeiro-Junho de 2022 Av. Professor Lúcio Martins Rodrigues, 443, Cidade Universitária, São Paulo, CEP: 05508-020 


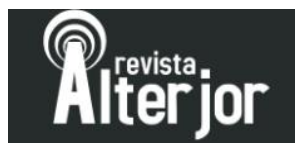

Vale salientar que, com a proximidade do pleito eleitoral, o blogueiro foi diminuindo paulatinamente as publicações em seu blog para postar as informações diretas e em maior número no Facebook. A estratégia antes utilizada de levar o usuário do SRS para visitar seu blog e assim o constituir como uma das páginas política mais acessadas de Pau dos Ferros/RN e região cedeu espaço a uma prioridade mais urgente: apoiar e colaborar com a visibilidade da campanha política e pretensa reeleição do então (à época das postagens) prefeito de Pau dos Ferros Fabrício Torquato.

Era como se a questão da credibilidade no jornalismo preterido no Blog do Capote não tivesse uma relação direta com o nenhum receio de se mostrar contundentemente partidário em seu perfil pessoal do Facebook que leva o mesmo nome do blog.

Assim, chamar o outro de mentiroso foi o último apelo de Mazinho Capote: "A turma dos desesperados, depois que perderam em todas as estratégias fajutas para mudar o resultado da eleição, inclusive numa pesquisa mentirosa, agora está apelando pra mais uma falácia: dizer que só pode votar com testemunha”. Esta foi a última forma de expurgar o outro publicada um dia antes da eleição.

Em se tratando do blog Política Pau-ferrense, escrito por Clodoeudes Fernandes, o expurgo do não-eu foi feito de maneira um pouco mais sutil e em menor número de publicações enquadradas nesta categoria (nove postagens em comparação a 11 publicações no Blog do Capote), embora tenha tido repercussões quantitativas através da interatividade bem maiores, quando comparadas às postagens feitas por Mazinho Capote.

No dia dois de agosto de 2016, Clodoeudes Fernandes postou em seu blog o título: "Editorial: Convenção que homologou candidatura à reeleição de Fabrício Torquato foi marcada por discursos de baixo nível e ausência de propostas", seguido do seguinte texto:

Continua repercutindo e muito nas esquinas e calçadas de Pau dos Ferros o baixo nível dos discursos proferidos por alguns oradores que foram escalados para falar durante a convenção do Partido Social Democrático (PSD), realizada no último domingo (31), na Escola Estadual 4 de Setembro, que homologou a candidatura à reeleição do prefeito Fabrício Torquato (PSD). 
Demonstrando que não estavam muito preocupados com a apresentação de propostas de trabalho para o desenvolvimento do município, tanto Fabrício Torquato quanto parte de seus apoiadores proferiram discursos de nível rasteiro, repletos de palavreados chulos, inclusive, tratando adversários com expressões que beiram a conotação sexual, apesar da presença de idosos, mulheres e crianças no local.

O festival de esculhambações contrariou bastante a postura que o gestor municipal vinha tentando repassar à população, pois, até pouco tempo, Fabrício adorava posar de "bom moço", "humilde" e "respeitador", mas, agora, ante a proximidade do pleito de outubro, o alcaide resolveu apelar à baixaria verbal ao invés de adotar um comportamento mais propositivo, nem que fosse apenas para manter uma conduta aceitável em cima do palanque.

Ademais, ao permitir abusos verborrágicos com a utilização de jargões pornográficos e insultos desmedidos, Fabrício nivelou a sua précampanha por baixo, detalhe: estratégia que sempre demonstrava repudiar antes de se aliar aos seus atuais correligionários, sendo que ele mesmo taxou publicamente um dos tais como "ficha suja por várias frentes".

Mas, tamanho erro grosseiro poderá custar caro para o grupo situacionista, já que as expressões impublicáveis pronunciadas durante a convenção do PSD ainda repercute negativamente nos quatro cantos da cidade, sobretudo pelo repúdio dos cidadãos de bem que reprovam a busca "canibalizada" pelo voto.

O que eu acho mais absurdo é que ainda tem pessoas que defendem esse estilo medieval de fazer política. Na verdade, se alguns eleitores passassem a exigir propostas ao invés de dar trela às acusações e ataques ferozes, essa eleição seria de melhor nível e, consequentemente, o debate seria outro.

No fim das contas, a postura dos candidatos passa sempre pelo entendimento dos eleitores. Quem se agradar das baixarias vai continuar a presenciá-las. Já os que desejam mais sensatez e equilíbrio buscarão afastar-se delas.

Assim como cada pessoa só costuma oferecer o que tem, existem aqueles que só recebem o que realmente querem.

Nesta "via de mão dupla", o eleitor é quem decide por onde quer "trafegar" (FERNANDES, 2016, online).

Neste caso, o redator se apropria de um dos gêneros textuais do jornalismo, o editorial, para explicitar que o que ele faz é jornalismo. Escolhe, portanto, um gênero opinativo para poder jornalisticamente defender um lado, um partido (apoio ao ex e atual prefeito Leonardo Rego). Embora enxergue no eleitor a importância da decisão final no pleito, o escritor tende a coagir a escolha: caso esta seja diferente da linha editorial do blog, ele a classifica de "baixa"; nas entrelinhas, de escolha sem sensatez e

\section{Revista ALTERJOR}

Grupo de Estudos Alterjor: Jornalismo Popular e Alternativo (ECA-USP)

Ano 12 - Volume 01 - Edição 25 - Janeiro-Junho de 2022 


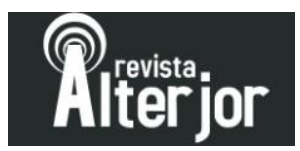

sem equilíbrio: “Quem se agradar das baixarias vai continuar a presenciá-las. Já os que desejam mais sensatez e equilíbrio buscarão afastar-se delas. Assim como cada pessoa só costuma oferecer o que tem, existem aqueles que só recebem o que realmente querem. Nesta "via de mão dupla", o eleitor é quem decide por onde quer "trafegar".

Mesmo que falando mais propriamente do jogo democrático, a publicação não deixou de usar expressões para depreciar o opositor: "o baixo nível dos discursos proferidos por alguns oradores", "não estavam muito preocupados com a apresentação de propostas de trabalho", "proferiram discursos de nível rasteiro, repletos de palavreados chulos", "festival de esculhambações", "baixaria verbal”, "abusos verborrágicos com a utilização de jargões pornográficos e insultos desmedidos”, "expressões impublicáveis" e "estilo medieval de fazer política". Diferente do Blog do Capote, o Política Pau-ferrense expurga diretamente o outro sem precisar referenciar as falas de terceiros. As palavras são do próprio "dono” da página.

Não é difícil perceber que, assim como a disputa eleitoral dos candidatos a prefeito, a disputa midiática no campo do discurso que se pretende jornalístico seguiu as ideias de apoio ou não à situação e à oposição; e o Política Pau-ferrense (apoiador nítido do ex-prefeito Leonardo Rego) era o principal rival do Blog do Capote (apoiador explícito do até então prefeito, Fabrício Torquato - hoje ex-prefeito, mas apoiador do grupo liderado por Nilton Figueiredo e Maria Rego, além de funcionário da atual gestão da prefeita Mariana Almeida). E em um acompanhamento ligeiro das publicações póspleito, isso continuou. Os blogs continuam exercendo seus papeis de oposição/expurgo e / ou apoio/defesa a determinados grupos políticos / partido.

Nesta conjuntura, é possível ponderar sobre esse discurso (especialmente no fim dele quando se imputa ao eleitor a responsabilidade de dar poder ou não ao que é considerado digno de expurgo), o conceito de "espírito estatal" proposto por Gramsci (1984), quando este fenômeno é confundido com a ideia de coletividade, uma vez que cada partido (um dos elementos fundamentais para determinação do "espírito estatal") seria a expressão de um grupo social; comungando assim com as palavras do blogueiro, nas quais o que seria de "baixo nível” só teria votos de pessoas de baixo nível, assim como quem procurasse "sensatez e equilíbrio" buscaria se afastar da "baixaria" e tinha 


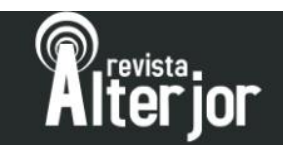

como exigência propostas que elevassem o debate político - o partido e grupo político seria então o resultado da expressão dos seus respectivos eleitores enquanto grupo social.

Semelhantemente ao Blog do Capote, a notícia é replicada no Facebook (perfil pessoal do redator) através de um link que leva o leitor / eleitor para o endereço do Política Pau-ferrense. E é, do mesmo modo, no SRS que a interatividade acontece. Entretanto, é nas publicações deste último que elas ocorrem de maneira substancialmente maior, como pode ser observado na Figura 05:

FIGURA 05: Interatividade no Facebook.

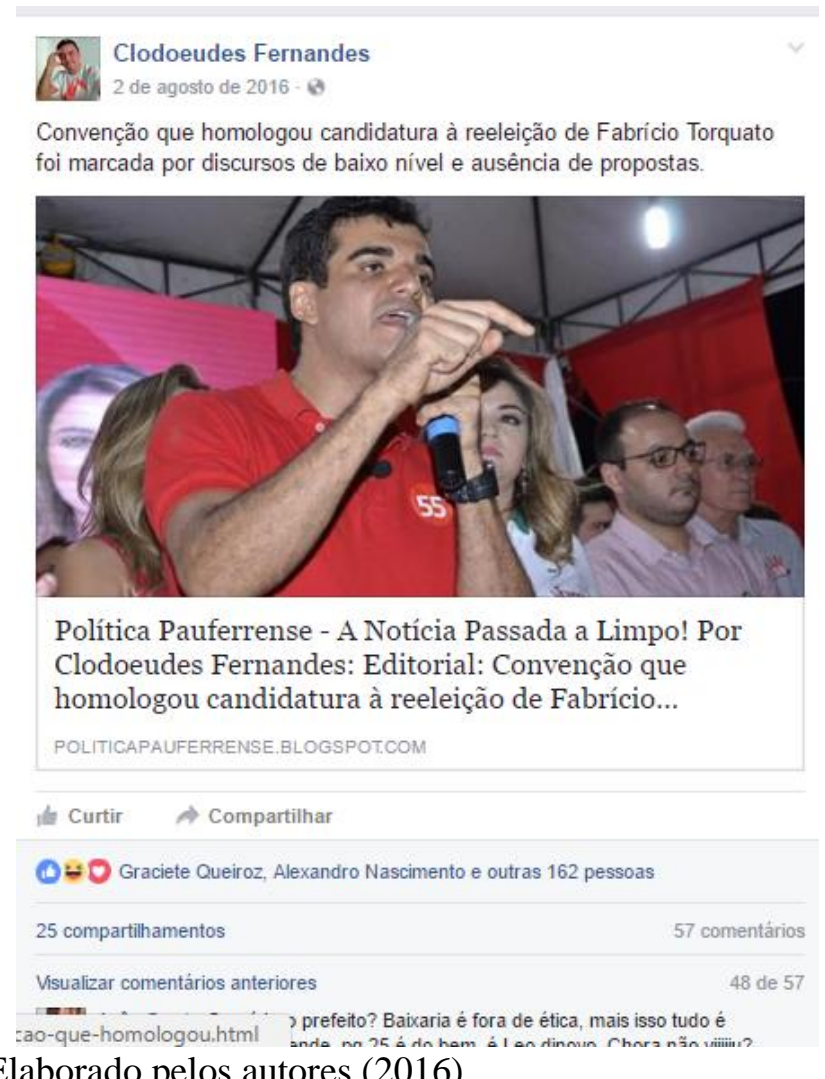

Fonte: Elaborado pelos autores (2016).

Em uma única postagem em seu perfil pessoal do Facebook, Clodoeudes Fernandes atinge o índice de mais de 160 curtidas, 25 compartilhamentos e 57 comentários, mesmo que nenhuma interatividade se efetive no blog.

\section{Revista ALTERJOR}

Grupo de Estudos Alterjor: Jornalismo Popular e Alternativo (ECA-USP)

Ano 12 - Volume 01 - Edição 25 - Janeiro-Junho de 2022 


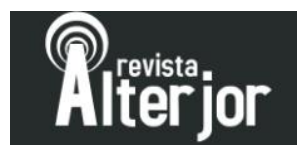

Noutra postagem, datada de 16 de setembro, o expurgo do outro se faz de forma contundente e se utilizando de estratégias semelhantes: "Repressão: Por buscarem liberdade para exercer cidadania, cargos comissionados começam a ser exonerados da gestão Fabrício Torquato":

Soa como um tremendo papo furado o chavão criado pelo marketing da campanha do prefeito candidato à reeleição, Fabrício Torquato (PSD), enaltecendo a "força do voto livre" da população, já que, de forma contraditória, nos últimos dias, o Diário Oficial do Município publicou a exoneração de alguns servidores comissionados, curiosamente, após estes manifestarem publicamente o desejo de votar no candidato da oposição, Leonardo Rêgo (DEM).

Detalhe: somente nesta sexta-feira (16) foram três exonerações, todas elas sob suspeitas de mera perseguição.

O mais interessante é que para justificar as demissões, claramente por motivações políticas, é suscitado o direito discricionário do gestor de manter no cargo somente as pessoas de sua mais irrestrita confiança, algo legal do ponto de vista jurídico, mas completamente imoral se levarmos em consideração que tais exonerações não utilizam como parâmetro o aspecto da eficiência técnica do servidor, apenas seu posicionamento político e de caráter pessoal.

Diante de tamanha repressão, é compreensível que alguns continuem a acompanhar o pleito eleitoral de forma discreta, afinal, conseguir emprego está difícil e, notadamente, no âmbito da esfera administrativa municipal, se alguém optar pela Liberdade ficará desempregado, restando a única opção de aguardar pelas bonanças que, possivelmente, virão com as "chuvas de janeiro".

Apesar de tudo, acredita-se que as táticas 'coronelistas' não tem surtido muito efeito, pois, pelo que dizem, nos intramuros do Poder Executivo muitos ainda aguardam caladinhos pelo momento certo para revidar à "mordaça institucional", sem temores quanto às desconfianças e ameaças veladas nos corredores da municipalidade.

Sem dúvidas, este é o retrato da "velha política" que deseja se instalar, definitivamente, em Pau dos Ferros (FERNANDES, 2016, online).

Atribuindo a Fabrício Torquato termos como "papo furado", "forma contraditória", "suspeitas de mera perseguição", “demissões por motivações políticas", "imoral”, "repressão", "táticas coronelistas", "mordaça institucional”, "velha política", o expurgo do não-eu é feito levando em consideração questões éticas do papel de um gestor do poder executivo municipal ao empregar ou demitir seus servidores de cargos de confiança, mesmo que o nome da função sugira um tom de pessoalidade e intimidade na relação empregatícia; na visão do autor da notícia, o prefeito deveria zelar pelo "o

Revista ALTERJOR

Grupo de Estudos Alterjor: Jornalismo Popular e Alternativo (ECA-USP)

Ano 12 - Volume 01 - Edição 25 - Janeiro-Junho de 2022

Av. Professor Lúcio Martins Rodrigues, 443, Cidade Universitária, São Paulo, CEP: 05508-020 


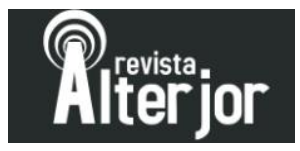

aspecto da eficiência técnica do servidor" e não apenas o seu posicionamento político e caráter pessoal.

Aqui a dimensão da dominação Legal - Burocrática ${ }^{16}$ é idealizada como algo digno de moralidade (imoral era o que Fabrício Torquato estava fazendo) e não presente nas ações de exoneração dos funcionários, que estariam ajustada às ações de Dominação Tradicional - Patriarcal, enquanto pertencente a "Estrutura estamental". Assim como explicou Weber (1982), embora os servidores não sejam pessoalmente patrimônio do prefeito, mas pessoas independentes, elas estão investidas em seus cargos por privilégio ou concessão do poder executivo municipal, o qual pode despojá-los ao bel prazer. Assim sendo, as interações seriam reguladas pela tradição, pelo privilégio, pelas relações de fidelidade patrimoniais e pela "boa vontade". Isso se materializa, na matéria, através de condições linguísticas presentes em "posicionamento político" e "caráter pessoal" como fatores determinantes para a demissão dos colaboradores.

Como exemplo de combinação de leitura interpretativa com outra categoria (embora não estudada aqui - o "Uso de conotações"), o trecho "virão com as "chuvas de janeiro"” pode implicar a ideia de que Leonardo Rego ganharia as eleições, trazendo "bonança" e total mudança do cenário político, assim como quando chegam as chuvas de janeiro, episódio determinante para ter um bom inverno naquela região sertaneja, fato que igualmente representaria mudança no cenário pau-ferrense.

Outros textos foram postados ainda nesta data, seguindo estratégias semelhantes às adotadas em outros momentos de publicação do blogueiro para expurgar o outro, como o uso do gênero editorial, de expressões linguísticas de depreciação, da preferência pela formação do discurso direto, sem grandes menções às falas de terceiros e de trazer para a cena política um pretenso discurso jornalístico, ainda que patrimonial, pautado em questões e expressões das relações éticas e democráticas: "Editorial: Comentários sobre aparência física de candidato a vice-prefeito em São Francisco do Oeste não acrescenta nada ao jogo democrático" e "Pau dos Ferros vivencia campanha atípica com ausência de divulgação de pesquisas eleitorais". Neste contexto, a

\footnotetext{
${ }^{16} \mathrm{Na}$ qual quem ordena é o superior, cujo direito de mando está legitimado por uma regra, lei, no âmbito de uma competência concreta delimitada e especializada conforme a utilidade e as exigências profissionais (Weber, 1982).
}

Revista ALTERJOR

Grupo de Estudos Alterjor: Jornalismo Popular e Alternativo (ECA-USP)

Ano 12 - Volume 01 - Edição 25 - Janeiro-Junho de 2022

Av. Professor Lúcio Martins Rodrigues, 443, Cidade Universitária, São Paulo, CEP: 05508-020 


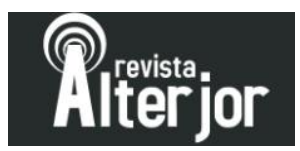

adjetivação tem menores números de ocorrências. Todas essas notícias divulgadas no dia 16 de setembro foram replicadas no Facebook, com grandes evidências quantitativas de interatividade. Assim, mesmo para levantar o debate sobre democracia, respeito às diferenças e ética, o blogueiro não o consegue (ou este não lhe é conveniente) fazer sem expurgar o não-eu.

\section{Algumas considerações para discussões outras}

Considerando o discurso jornalístico (ou que se pretende jornalístico porque pretende o estatuto da verdade e da credibilidade) um termo essencialmente que pressupõe uma ação política e, portanto, diretamente relacionado com as noções de Democracia no Brasil, foi-se necessário relacioná-lo prioritariamente a um outro campo de disputada de poder que exerce uma centralidade vital na sociedade atual: a mídia na Internet, especificamente o jornalismo online e em rede; exatamente porque é também nessa plataforma que se exercem e se legitimam não apenas as relações de dominação e desigualdade social (inclusive e sobretudo através do discurso, como previram as Análises Críticas do Discurso).

Por isso, coube bem se aprovisionar dos modelos de Análise crítica de Discurso, para partir de alguns princípios de dominação previstos por Max Weber (1999) dominação legal / burocrática, tradicional / patriarcal e carismática - para relacioná-los com a publicação dos textos preteridos como jornalismo político na rede, em interiores que muitas vezes são invisíveis aos interesses e pautas da grande e tradicional mídia e dos circuitos nacionais de investigação científica. Aqui pode-se perceber que dominação política e discurso político quase sempre se entrelaçam enquanto ações para forjar uma estrutura dorsal a que se entende o patrimonialismo. Basta perceber que a dominação política em cidades interioranas como Pau dos Ferros / RN se alterna no poder executivo junto com a narrativa de seus respectivos blogs de apoio, os quais ora são situação; ora oposição; mas sempre presentes no jogo democrático e arrogando para si o estatuto da credibilidade jornalística.

Revista ALTERJOR

Grupo de Estudos Alterjor: Jornalismo Popular e Alternativo (ECA-USP)

Ano 12 - Volume 01 - Edição 25 - Janeiro-Junho de 2022 Av. Professor Lúcio Martins Rodrigues, 443, Cidade Universitária, São Paulo, CEP: 05508-020 


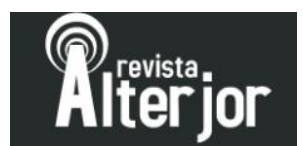

\section{Referências}

CANAVILHAS, João. Jornalismo e Convergência: permanente renovação. In: ERC Digital Media Portugal. 2015, p. 27-34.

CASTELLS, Manuel. O poder da identidade. São Paulo: Paz e Terra, 1999.

DIJK, Teun A. van. Como a Rede Globo manipulou o impeachment da presidente do Brasil, Dilma Rousseff. São Paulo: Carta Maior, 2016. Disponível em: <http://cartamaior.com.br/?/Editoria/Midia/Como-a-Rede-Globo-manipulou-o-

impeachment-da-presidente-do-Brasil-Dilma-Rousseff/12/37490>. Acesso em: $21 \mathrm{dez}$. 2016.

DIJK, Teun A. van. Discurso e poder. Tradução: Judith Hoffnagel, Ana R. Vieira, Leonardo Mozdzenski, Benedito Gomes Bezerra, Rodrigo Castro e Karina Falcone. São Paulo: Contexto, 2010.

DIJK, Teun A. van. Discurso e contexto: uma abordagem sociocognitiva. Tradução: Rodolfo Ilari. São Paulo: Contexto, 2012.

DIJK, Teun A. van. What is Political Discourse Analysis? Key-note address Congress Political Linguistics. Antwerp, 1995. In: BLOMMAERT, Jan; BULCAEN, Chris (Orgs.). Political linguistics. Amsterdam: Benjamins, 1997, p. 11-52. Disponível em: $<$ http://discourses.org/OldArticles/What\%20is\%20Political\%20Discourse\%20Analysis. pdf $>$. Acesso em: 11 de maio de 2020.

FAIRCLOUGH, Norman. Language and power. Londres: British Library Cataloguing in Publication Data, 1989.

FAORO, Raymundo. Os donos do poder: formação do patronato político brasileiro. 3 ed. Porto Alegre: Globo, 2001.

GILL, Rosalind. Análise de Discurso. In: BAUER, Martin W.; GASKELL, George (Orgs.). Pesquisa qualitativa com texto: imagem e som: um manual prático. Tradução de Pedrinho A. Guareschi. Petrópolis: Vozes, 2002.

GRAMSCI, Antonio. Maquiavel, a política e o estado moderno. Rio de Janeiro: Civilização Brasileira, 1984.

HOLANDA, Sérgio Buarque de. Raízes do Brasil. São Paulo: Companhia das Letras, 2011.

MIELNICZUK, Luciana. Sistematizando alguns conhecimentos sobre jornalismo na web. In.: MACHADO, Elias; PALÁCIOS, Marcos (Org). Modelos de Jornalismo Digital. Salvador: Edições GJOL, 2003.

SENA, Patrícia Rakel de Castro. O sertão potiguar comunica: midiatização e práticas sociais. Ou como a recepção da pauta política se desdobra em práticas sociais em Pau dos Ferros. 2011. 102 f. Dissertação (Mestrado em Comunicação midiática: práticas sociais e produção de sentido) - Universidade Federal do Rio Grande do Norte, Natal, 2011.

\footnotetext{
Revista ALTERJOR

Grupo de Estudos Alterjor: Jornalismo Popular e Alternativo (ECA-USP)

Ano 12 - Volume 01 - Edição 25 - Janeiro-Junho de 2022

Av. Professor Lúcio Martins Rodrigues, 443, Cidade Universitária, São Paulo, CEP: 05508-020
} 


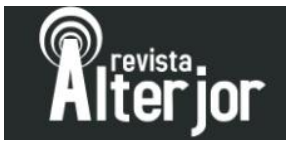

SERRA, Joaquim Paulo. Informação e sentido: o estatuto epistemológico da informação. Covilhã/Portugal: Editora da Universidade da Beira Interior, Livros Labcom, 2003.

SOUZA, Jessé. A radiografia do golpe: entenda como e por que você foi enganado. Rio de Janeiro: LeYa, 2016.

WEBER, Max. Os três tipos puros de dominação. In: COHN, Gabriel (Org. da Coletânea: Grandes Cientistas Sociais). Max Weber: sociologia. Tradução Amélia Cohn e Gabriel Cohn. São Paulo: Ática, 1982.

WEBER, Max. Economia e Sociedade: Fundamentos da Sociologia Compreensiva. Vol. 2. Tradução de Regis Barbosa e Karen Elsabe Barbosa; Revisão técnica de Gabriel Cohn. São Paulo: Editora Universidade de Brasília, Imprensa Oficial do Estado de São Paulo, 1999. 